\title{
THE COURT OF LAST RESORT: SEEKING REDRESS FOR VICTIMS OF ABU-GHRAIB TORTURE THROUGH THE ALIEN TORT CLAIMS ACT
}

\author{
Atif Rehman* \\ INTRODUCTION
}

[W]e have got people whose basic human rights are being violated by American corporations for profit. And we're interested in holding these companies accountable for their war crimes ... [J]ust because we are at war doesn't mean it's the wild, wild west and the rules don't apply.

-Craig T. Jones - An attorney representing victims of AbuGhraib prison abuse.

Imagine returning to your native homeland in search of peace and prosperity after your people are "liberated" by the removal of a brutal dictator. Imagine after returning home, you are driving and U.S. military officers, whom you believe are your friends, stop your car as part of a random check. To your surprise, they confiscate your car, cash, and jewelry. You are then thrown into a prison, but you are never told why. In prison, things quickly take a turn for the worse; you are urinated on, beaten, and sodomized. The abuse is all part of a plan to break you down so that you will provide better intelligence during interrogations. But you do not know anything. You profess your innocence, but no one will listen. The abuse continues. Several weeks later you are released, battered and broken. You still do not know why you were picked up in the first place. No explanation. No apology. Imagine the shock. Imagine the outrage.

This was the horror a Swedish citizen named Saleh faced after returning to Iraq following the removal of Saddam Hussein. ' Saleh is not a terrorist, insurgent, or Baathist. ${ }^{2} \mathrm{He}$ is just a regular Iraqi, one of many who were picked

*J.D. Candidate 2006, Indiana University School of Law - Indianapolis; BBA 2000, Wilfrid Laurier University. I would like thank Professor Maria Pabon Lopez as well as the members of the Indiana International and Comparative Law Review for all of their guidance and feedback. Most importantly, I would like to thank my wife, Aisha, for her unconditional support, encouragement, and patience throughout law school.

1. See Seth Hettena, Iraqi in Abu Ghraib Saw Captors Rape, Kill Detainees, at www.indymedia.org.uk/en/2004/07/294376.html (July 01, 2004).

2. See id. 
up in random stops throughout Iraq and thrown into the Abu-Ghraib prison. ${ }^{3}$ While at Abu-Ghraib, he was allegedly abused by U.S. military personnel and civilian contractors from U.S. corporations. ${ }^{4}$

To make matters worse, upon returning home, Saleh learned that the civilian contractors responsible for his abuse would go unpunished because, as non-soldiers, they are immune from prosecution under military law. ${ }^{5}$ A civil suit against his aggressors in an Iraqi court is also impossible because of an executive order passed by the Coalition Provisional Authority (CPA) which provides immunity from prosecution to all contractors in Iraqi courts. ${ }^{6}$ The civilian contractors in Iraq are essentially operating in lawlessness. ${ }^{7}$

Fortunately, Saleh and others like him may find solace in an old statute, 28 U.S.C. $\$ 1350$, the Alien Tort Claims Act (ATCA). ${ }^{8}$ The ATCA enables aliens to bring claims in U.S. courts for certain actions that fall into a narrow category defined as violations of "laws of nations." Violations of "laws of nations" are limited to a small number of egregious human rights violations, such as torture, genocide, and summary execution. ${ }^{9}$

The ATCA has been used to promote justice by bringing perpetrators of human rights violations in other countries before the U.S. legal system. Specifically, it potentially provides victims of abuse at Abu-Ghraib with an avenue to bring civil actions against the corporations who had a hand in their abuse, corporations that otherwise would go unpunished.

This Note will argue that claims by victims of Abu-Ghraib prison abuse are within the scope of the ATCA. Part I will focus on the background of AbuGhraib, the problems that arose at the prison, the role of the civilian contractors, and the legal remedies available to victims. Part II will focus on the modern history of the ATCA and its past use. Part III will focus on the Supreme Court decision in Sosa v. Alvarez Machain, the recent decision that sought to clarify the interpretation of the ATCA. ${ }^{10}$ Part IV will discuss how the victims of AbuGhraib prison abuse may be able to establish the liability of their abusers. Finally, Part V will briefly explain some of the claims that have already been filed on behalf of Abu-Ghraib victims and highlight some of the defenses that have been raised by the private contractor defendants.

3. Id.

4. Id.

5. Joanne Mariner, Private Contractors Who Torture, at http://writ.news.findlaw.com/mariner/20040510.html (May 10, 2004).

6. Id.

7. See id.

8. Marie Beaudette, Seeking Payback; Money for Abused Iraqis Won't Come Easily Nor Without Some Creative Legal Arguments, LEGAL TIMES, June 28, 2004, at 1.

9. Warren Richey, Ruling Makes it Harder for Foreigners to Sue in US Courts, CHRISTIAN SCIENCE MONITOR, (June 30, 2004), available at http://www.globalpolicy.org/intljustice/atca/2004/0630hard.htm.

10. See Sosa v. Alvarez-Machain 542 U.S. 692 (2004). 


\section{BACKGROUND}

On March 19, 2003, the President of the United States, George W. Bush, acting with Congressional authorization, commenced military operations against Iraq. " The operation involved over 460,000 ground troops and 41,000 aircraft sorties. $^{12}$ Just twenty-one days later, on April 9, 2003, the city of Baghdad fell. ${ }^{13}$ Once the U.S. military established control over Iraq, they established several facilities to house and interrogate detainees who had potential intelligence value. $^{14}$ There were at least seven of these facilities; the largest facility was Abu-Ghraib. ${ }^{15}$

Abu-Ghraib, while operating under the rule of Saddam Hussein, was notorious for torture, weekly executions, and vile living conditions. ${ }^{16}$ However, the looting that followed the fall of Saddam left Abu-Ghraib deserted and barren. $^{17}$

In the spring of 2003 , in the face of a growing insurgency, U.S.-led coalition forces needed facilities to detain suspected insurgents and gather intelligence. $^{18}$ As a result, the coalition forces took control of Abu-Ghraib. They had the floors tiled and the cells cleaned and repaired. ${ }^{19}$ They added toilets, showers, and a new medical center. ${ }^{20}$ Abu-Ghraib became a U.S. military prison. ${ }^{21}$

By the fall of 2003 the U.S. military was housing several thousand prisoners at Abu-Ghraib, including women and teenagers. ${ }^{22}$ Most of the prisoners were civilians, many of whom were picked up, like Saleh, in random military sweeps and at highway checkpoints. ${ }^{23}$ The prisoners fell into three loosely defined categories: "common criminals, security detainees suspected of

11. Authorization for Use of Military Force Against Iraq Resolution of 2002, H.R. REP. No. 107-243, at 1 (2001), available at http://www.house.gov/international_relations/democratic/hjres114.pdf (last visited Feb. 18, 2006).

12. T. Michael Moseley, U.S. Air Force Operation Iraqi Freedom by the Numbers, 3,7 (April 30, 2003), at http://www.globalsecurity.org/military/library/report/2003/uscentaf_oif_report_30apr2003.pdf.

13. Id. at 15.

14. Memorandum of Points and Authorities in Support of the Motion of Defendant Titan's Motion to Dismiss Saleh v. Titan Corp. (S.D. Cal. 2004) (NO.04-CV-1 143) [hereinafter Titan's Motion to Dismiss].

15. Id.

16. Seymour M. Hersh, Chain Of Command: The Road From 9/11 to Abu Ghraib 20 (Harper Collins 2004).

17. Id. at 21.

18. See id.

19. Id.

20. Id.

21. Id.

22. Seymour M. Hersh, Torture at Abu Ghraib, THE New YoRkER, May 10, 2004, http://www.newyorker.com/fact/content/2040510fa_fact (posted Apr. 30 2004).

23. See HERSH, supra note 16, at 21. 
'crimes against the Coalition', and a small number of suspected 'high-value' leaders of the insurgency against the coalition forces." 24

The $800^{\text {th }}$ Military Police Brigade, an army unit based in Uniondale, New York, was responsible for running the Abu-Ghraib prison. ${ }^{25}$ Although AbuGhraib was a U.S. military prison, due to the shortage of interrogators and interpreters, the U.S. government outsourced interrogation and translation duties to private, "for-profit" corporations. ${ }^{26}$ In fact, of the thirty-seven interrogators at Abu-Ghraib prison, twenty-seven did not belong to the U.S. military. ${ }^{27}$ Those twenty-seven interrogators were employees of a Virginiabased company, CACI International ("CACI"). ${ }^{28}$ Additionally, twenty-two of the linguists who assisted in the translation of interrogations were employees of another corporation, Titan International ("Titan"). ${ }^{29}$

In June 2003, Janis Karpinski, an Army Reserve General, was put in charge of the $800^{\text {th }}$ Military Police Brigade. ${ }^{30}$ Karpinski had no prior experience running a prison system. ${ }^{31}$ She quickly lost control of the prison, and numerous reports of prison mistreatment began to surface. ${ }^{32}$ The International Committee of the Red Cross (ICRC) began to express concerns about the treatment of detainees. ${ }^{33}$ Karpinski wrote to the ICRC in response to their concerns, stating that military necessity required the isolation of some prisoners and that they were not entitled to full Geneva Convention protections. $^{34}$ The reports of abuse of Iraqi detainees continued, as well as reports of escapes and a lack of accountability of U.S. personnel. ${ }^{35}$ In January 2004, General Karpinski was suspended and a major investigation into the Army's prison system was authorized by the Senior Commander in Iraq, Lieutenant General Richard S. Sanchez. ${ }^{36}$

On January 31, 2004, the U.S. Central Command appointed an officer, Major General Antonio M. Taguba, to investigate the conduct of the $800^{\text {th }}$ Military Police Brigade at Abu-Ghraib. ${ }^{37}$ Over the course of a month, Taguba and his team reviewed numerous photos and videos taken by U.S. personnel at the prison. In addition, they analyzed witness statements by military police and

24. Id.

25. See Sean Murphy, U.S. Abuse of Iraqi Detainees at Abu Ghraib Prison, 98 AM. J. INT'L L. 591, 594 (2004).

26. Lynda Hurst, The Privatization of Abu Ghraib, THE TORONTO STAR, May 16, 2004, http://www.commondreams.org/headlines04/0516-02.htm.

27. Id.

28. Id.

29. Id.

30. Hersh, supra note 22.

31. Id.

32. Id.

33. Murphy, supra note 25, at 593.

34. Id.

35. Id.

36. HERSH, supra note 16, at 21-22.

37. Murphy, supra note 25, at 594. 
intelligence personnel, potential suspects, and detainees. ${ }^{38}$ In late February 2004, Major General Antonio M. Taguba's findings were published. ${ }^{39}$ The findings were startling. He found that between October and December of 2003, there were numerous instances of "sadistic, blatant, and wanton criminal abuses" at Abu-Ghraib. ${ }^{40}$ Some of the abuses included:

Breaking chemical lights and pouring the phosphoric liquid on detainees; pouring cold water on naked detainees; beating detainees with a broom handle and a chair; threatening male detainees with rape; allowing a military police guard to stitch the wound of a detainee who was injured after being slammed against the wall in his cell; sodomizing a detainee with a chemical light and perhaps a broom stick, and using military working dogs to frighten and intimidate detainees with threats of attack, and in one instance actually biting a detainee. ${ }^{41}$

According to the report, military intelligence officers, CIA personnel, and private contactors "actively requested that MP [Military Police] guards set physical and mental conditions for favorable interrogation of witnesses. ${ }^{, 42}$ The Taguba report provided concrete evidence substantiating the allegations that victims like Saleh had been making. ${ }^{43}$ The findings of the report also exposed the extent of private corporation involvement in the interrogation and abuse of prisoners. ${ }^{44}$

Private contractors have played an unprecedented role in many aspects of the Iraqi conflict, including detention and interrogation of prisoners at AbuGhraib. Private companies like CACI and Titan paid their employees salaries far greater than the U.S. Military paid its soldiers for similar tasks. ${ }^{45}$ Furthermore, since these private contractors are U.S. civilians, they are not bound by military rules or the Geneva Convention. ${ }^{46}$ While soldiers involved in wrongdoings can face a court martial, contractors are considered mercenaries operating outside of the military chain of command. ${ }^{47}$ In addition to immunity from military law, contractors in Iraq operate outside the reach of Iraqi law.

38. HERSH, supra note 16 , at 22.

39. Id.

40. Id.

41. Id.

42. Murphy, supra note 25 , at 595.

43. See generally Maj. Gen. Antonio M. Taguba, Article 15-6, Investigation of the $800^{\text {th }}$ Military Policy Brigade, (2004) (on file with author) (describing the abuse inflicted on prisoners while being held at Abu-Ghraib) [hereinafter Taguba Report].

44. See id.

45. HERSH, supra note 16 , at 33.

46. Robin Rowland, The Privatization of War Crimes, CBC News Online (May 6, 2004), at http://www.cbc.ca/news/background/iraq/abughraib_privatization.html.

47. Steve Sanders, A Tool For Torture Cases, 45 BRowARD DAlLY BUS. REV. 135, June 21,2004 , at 6 . 
Before Ambassador Paul Bremer left Iraq on June 28, 2004, he passed Order $17^{48}$ giving complete immunity to contractors and military personnel from prosecution in Iraqi courts for killing Iraqis or destroying local property. ${ }^{49}$

Ever since the uncovering and subsequent media exposure of the abuse at Abu-Ghraib, several soldiers have been charged. The charges brought by the U.S. Army against its soldiers include physical and sexual abuse, conspiracy, dereliction of duty, cruelty, maltreatment, assault, and indecent acts. ${ }^{50}$ Soldiers

48. Coalition Provisional Authority Order Number 17 (June 27, 2004) (revised) (on file with author):

Pursuant to my authority as head of Coalition Provisional Authority (CPA), and under the laws and usages of war, and consistent with relevant U.N. Security Council resolutions, including Resolutions 1483 (2003), 1511 (2003) and 1546 (2004), ...I hereby promulgate the following:

Sec 2. Iraqi Legal Process

1) Unless provided otherwise herein, the MNF [Multinational Force], the CPA, Foreign Liaison Missions, their Personnel, property, funds and assets, and all International Consultants shall be immune from the Iraqi legal process.

2) All MNF, CPA and Foreign Liaison Mission Personnel and International Consultants shall respect the Iraqi laws relevant to those Personnel and Consultants in Iraq including the Regulations, Orders, Memoranda and Public Notices issued by the Administrator of the CPA.

3) All MNF, CPA and Foreign Liaison Mission Personnel, and International Consultants shall be subject to exclusive jurisdiction of their Sending States. They shall be immune from any form of arrest or detention other than by persons acting on behalf of their Sending States, except that nothing in this provisions shall prohibit MNF Personnel from preventing acts of serious misconduct by the above-mentioned Personnel or Consultants, or otherwise temporarily detaining such Personnel or Consultants who pose a risk of injury to themselves or others, pending expeditious turnover to the appropriate authorities of the Sending State. In all such circumstances, the appropriate senior representative of the detained person's Sending State in Iraq shall be notified immediately.

4) The Sending States of the MNF Personnel shall have the right to exercise within Iraq any criminal and disciplinary jurisdiction conferred on them by the law of that Sending State over all persons subject to the military law of that Sending State.

Sec 4. Contractors

1) Sending States may contract for any services, equipment, provisions, supplies, material, other goods, or construction work to be furnished or undertaken in Iraq without restriction as to choice of supplier or Contractor. Such contracts may be awarded in accordance with the Sending State's laws and regulations.

3) Contractors shall be immune from Iraqi legal process with respect to acts performed by them pursuant to the terms and conditions of a Contract or any subcontract thereto. Nothing in this provision shall prohibit MNF Personnel from preventing acts of serious misconduct by Contractors, or otherwise temporarily detaining any Contractors who pose a risk of injury to themselves or others, pending expeditious turnover to the appropriate authorities of the Sending State. In all such circumstances, the appropriate senior representative of the Contractor's Sending State in Iraq shall be notified.

Id.

49. Robin Wright, U.S. Immunity in Iraq Will Go Beyond June 30, WASH. PosT, June 24, 2004, at A1, http://www.washingtonpost.com/wp-dyn/articles/A757-2004Jun23.html.

50. Id. 
have defended themselves by claiming they were just following orders from military intelligence personnel, which include interrogators and translators from CACI and Titan. ${ }^{51}$

The ATCA may play a unique role in holding civilian contractors, like CACI and Titan, liable for their alleged conduct, as well as provide civil remedies to the victims of the abuse. ${ }^{52}$ The ATCA was passed as part of the Judiciary Act of $1789 .^{53}$ The Act has enabled aliens who have been victims of certain international human rights abuses sustained abroad to bring suit against their abusers. ${ }^{54}$

The ATCA, however, is both old and vague. ${ }^{55}$ The language of the statute makes no assertion about legal rights. It simply provides that "district courts shall have original jurisdiction of any civil action by an alien for a tort only committed in violation of the law of nations. ..."56 This has left much room for interpretation.

Although the ATCA has been surrounded with debate over its intended interpretation, recent rulings have helped clarify its interpretation. If victims of Abu-Ghraib prison abuse are able to prove that civilian contractors were directly involved in their abuse, and that the abuse amounted to "torture" in violation of the "laws of nations," they will likely be successful in using the ATCA as a tool for recovery. The decisions in three major ATCA cases provide legal precedent for victims, like Saleh, to draw upon in establishing a case against their alleged corporate abusers. First, Filartiga v. Pena-Irala ${ }^{57}$ a case that outlined the present day violation of "laws of nations," provides the foundation for a modern ATCA action. ${ }^{58}$ Second, Kadic v. Karadzic, ${ }^{59}$ the first case to allow an ATCA action against a private party, was instrumental in broadening the scope of the ATCA to include violations by non-state actors. ${ }^{60}$ Finally, Sosa v. Alvarez-Machain ${ }^{61}$ re-affirmed that the ATCA is available to be used for a limited number of violations, including torture. ${ }^{62}$

\section{MODERN HISTORY OF ATCA}

Congress passed the ATCA in 1789, and President George Washington

51. Julian Borger, U.S. Military in Torture Scandal, GUARDIAN UNLIMITED, Apr. 30, 2004, www.guardian.co.uk/Iraq/Story/0.2763.1206725.00.html.

52. See Filartiga v. Pena-Irala, 630 F. 2d 876 (2d. Cir. 1980).

53. Sanders, supra note 47.

54. Gina Bateson, Alien Tort Claims Act in Jeopardy, Six DegreEs 42, at http://www.stanford.edu/group/sixdegrees/journal/spring04.pdf (Spring 2004).

55. Id.

56. 28 U.S.C. $\$ 1350(2005)$.

57. Filartiga, 630 F.2d at 876.

58. See id.

59. Kadic v. Karadzic, 70 F.3d 232 (2d. Cir. 1995).

60. See id.

61. 542 U.S. 692 (2004).

62. See id. 
signed it into law. ${ }^{63}$ The original Act held that district courts "shall also have cognizance, concurrent with the courts of the several States, or the circuit courts, as the case may be, of all causes where an alien sues for a tort only in violation of the law of nations or a treaty of the United States." ${ }^{, 64}$ The statute has seen slight modifications since its original enactment. ${ }^{65}$ "[The ATCA] now reads ... 'The district courts shall have original jurisdiction of any civil action by an alien for a tort only, committed in violation of the law of nations or a treaty of the United States." $" 66$

Congress enacted the ATCA soon after the ratification of the U.S. Constitution. ${ }^{67}$ Many legal scholars believe the Act was enacted to deal with the problem of piracy committed at sea ${ }^{68}$ The ATCA was seldom used for nearly 200 years. Between 1789 and 1979, the ATCA was used less than twenty-five times, and only two courts ever upheld jurisdiction under Act. ${ }^{69}$ Then, in the 1979 case of Filartiga $v$. Pena Irala ${ }^{70}$ the plaintiffs won a judgment under the ATCA. Suddenly, the ATCA captured the attention of human rights activists in the United States. ${ }^{71}$

The Filartiga story is a remarkable one, involving the 1976 murder of a young man, Joelito Filartiga, by an agent of Paraguayan dictator, Alfredo Stroessner. ${ }^{72}$ The agent who supervised the torture and murder of Joelito was Americ Noerberto Pena-Irala. ${ }^{73}$ Pena-Irala eventually moved to New York from Paraguay. ${ }^{74}$ Jolelito's sister, Dolly, who also later came to the United States, learned that there was a possibility of bringing a civil suit against her brother's killer. ${ }^{75}$ With the help of the Center for Constitutional Rights (CCR), Dolly filed a suit under the ATCA against Pena-Irala. ${ }^{76}$

Federal Judge Eugene Nickerson was the first to hear the case. ${ }^{n}$ Judge Nickerson declined to extend jurisdiction to the civil suit. ${ }^{78}$ In his view, the statute did not give jurisdiction to a foreign national for a tort committed in Paraguay. ${ }^{79}$

63. Bateson, supra note 54 , at 42 .

64. Sosa, 542 U.S. at 713 (citation omitted).

65. Id.

66. Id. (quoting 28 U.S.C. \& 1350).

67. Gary Hufbauer \& Nicholos Mitrokostas, International Implications of the Alien Tort Statute, 16 St. Thomas L. REv. 607, 609 (2004).

68. Bateson, supra note 54 , at 42.

69. Hufbauer \& Mitrokostas, supra note 67, at 609.

70. Filartiga, 630 F. $2 \mathrm{~d}$ at 876.

71. Hufbauer \& Mitrokostas, supra note 67, at 610.

72. RICHARD ALAN WHITE, BREAKING SILENCE: THE CASE THAT CHANGED THE FACE OF HUMAN RIGHTS xi (Georgetown University Press 2004).

73. Bateson, supra note 54 , at 43.

74. Id.

75. WHITE, supra note 72 , at xi.

76. Id.

77. Id.

78. Id.

79. Id. 
The CCR lawyers and Dolly were successful in their appeal to the Second Circuit. $^{80}$ The Appellate Court reversed the trial judge and remanded the case to the District Court for a hearing. ${ }^{81}$ In reversing, the appellate court ruled that Joelito was tortured and killed by a public official, conduct which was in clear violation of the norms of international law. ${ }^{82}$ The Court relied on Article 5 of the Universal Declaration of Human Rights, which states that "no one shall be subjected to torture or to cruel, inhuman or degrading treatment or punishment." ${ }^{\text {"83 }}$ The ensuing trial resulted in a decision that ordered the defendant to pay $\$ 10.375$ million to the Filartigas in compensatory and punitive damages. $^{84}$

The Filartiga case was instrumental in establishing the reach of the ATCA and in identifying torture as a violation of the law of nations. The court acknowledged the universal condemnation of torture in numerous international agreements and its renunciation by most of the world. ${ }^{85}$ The court held that torture committed by a state official against one held in detention violates international human rights law and, hence, the law of nations. ${ }^{86}$ Second Circuit Justice Irving Kaufman explained, "[t]he torturer has become like the pirate and slave trader before him - hostis humanis generis, an enemy of all mankind."87 Filartiga established that the ATCA would provide jurisdiction over a state torturer found and served with due process by an alien within U.S. borders. ${ }^{88}$

Fifteen years after the Filartiga decision, the reach of the ATCA was extended to include private parties in the landmark decision Kadic v. Karadzic. 89 In Kadic, the plaintiffs were Croat and Muslim citizens of BosniaHerzegovina, formerly a republic of Yugoslavia. ${ }^{90}$ The Croats and Muslims were victims of various atrocities, including rape, forced prostitution, forced impregnation, torture, and summary execution. ${ }^{91}$ This genocidal campaign by Serbian military forces occurred during the Bosnian civil war. ${ }^{92}$ The defendant, Karadzic, was one of three Presidents of a self-proclaimed Bosnian-Serb republic within Bosnia-Herzegovina. ${ }^{93}$ In his command, Karadzic had authority

80. Id.

81. Id.

82. Id.

83. Id.

84. Id.

85. Filartiga, 630 F.2d at 880 .

86. Id. at 884 .

87. Id. at 890 .

88. Corporate Liability for Violations of International Human Rights Law, 114 HARV.L. REv. 2025, 2034 (2001).

89. Kadic, 70 F.3d at 232.

90. Id. at 236.

91. Id.

92. Id.

93. Id. 
over the Bosnian-Serb military forces and was directly responsible for the human rights violations. ${ }^{94}$

In 1993, Karadzic was admitted to the United States as an invitee of the United Nations in New York. ${ }^{95}$ While in New York, he was personally served with the summons and complaint in an ATCA action brought by the Bosnian victims of his abuse. ${ }^{96}$ The U.S. District Court for the Southern District of New York dismissed the suit for lack of subject matter jurisdiction. ${ }^{97}$ The court concluded that "acts committed by non-state actors do not violate the law of nations." The Bosnian-Serb warring military faction was not a recognized state, and members of Karadzic's faction did not act under the color of any recognized state law; accordingly, the ATCA could not provide a remedy for their actions. ${ }^{99}$

The issue on appeal concerned the scope of the ATCA, specifically whether violations of the law of nations may be remedied when committed by non-state actors. ${ }^{100}$ Karadzic claimed that his alleged actions were not violations of international law because he was a private individual, not a state or a person acting under color of state law. ${ }^{101}$

The court ruled that the law of nations, as understood in the modern era, does not confine its reach to state actors. ${ }^{102}$ It stated, "we hold that certain forms of conduct violate the law of nations whether undertaken by those acting under the auspices of a state or only as private individuals."103 The court then went on to identify genocide and war crimes as violations of the law of nations that did not require state action. ${ }^{104}$ The court recognized that murder, rape, torture, and arbitrary detention of civilians committed in the course of hostilities are war crimes. ${ }^{105}$

Based on Kadic's precedent, the victims of Abu-Ghraib can justify ATCA jurisdiction over private contractors. Even though the contractors are not state actors, the victims were allegedly tortured during the course of a war. If the abuse imposed by private contractors during the war was severe enough to be classified as torture, it would meet the Kadic definition of a war crime.

The Kadic decision, which for the first time permitted actions against private entities, opened up the possibility of suing corporations. ${ }^{106}$ Naturally,

\footnotetext{
94. Id.

95. Id. at 237.

96. Id.

97. Id.

98. Id.

99. Id.

100. Id. at 236.

101. Id. at 239.

102. Id. at 239.

103. Id.

104. Id. at 241-43.

105. Id. at 242.
}

106. Francisco Rivera, A Response to the Corporate Campaign Against the Alien Tort Claims Act, 14 IND. INT'L \& CoMP. L. REV. 251, 254 (2003). 
this caught the attention of the business community, particularly those doing business abroad. Corporations suddenly feared lawsuits arising from human rights violations in countries in which they did business. ${ }^{107}$ In the years since Kadic, a few companies have been named as defendants in suits alleging that they abetted human rights violations through their activities in countries governed by repressive regimes. ${ }^{108}$ To date, however, no U.S. corporation has ever been held liable under the Act. ${ }^{109}$ Nevertheless, the opposition from the business community is strong.

The opponents of the ATCA fear that it is being used too expansively, and they are determined to limit its use. ${ }^{110}$ Large corporations fear that they will be an easy target by plaintiffs who see them as deep pockets for recovery. ${ }^{11}$ Opponents suggest that the ATCA is being used to abuse the U.S. judicial system and that such abuse will result in enormous legal costs to corporations that engage in business abroad. ${ }^{112}$ According to John E. Howard, Vice President of International Policy and Programs for the U.S. Chamber of Commerce, "U.S. national interests require that we not allow the continuing misapplication of this $18^{\text {th }}$ century statute to $21^{\text {st }}$ century problems by latter day pirates of the plaintiffs' bar." 113

On the other hand, human rights activists believe that the Act should be interpreted broadly and used as a tool to defend human rights violations abroad. ${ }^{114}$ ATCA proponents advocate civil lawsuits as an appropriate method of holding companies accountable for their role in international human rights violations. ${ }^{115}$

Parties on both sides of the issue anxiously awaited the Supreme Court decision of Sosa v. Alvarez-Machain, ${ }^{116}$ which promised to clarify the scope of the ATCA.

107. See id.

108. Sanders, supra, note 47 ; see Doe v. Unocal, 395 F.3d $932\left(9^{\text {th }}\right.$ Cir. 2002) (plaintiffs allege that Unocal was complicit in forced labor, forced relocation, and torture carried out by the Burmese military in the building of the Yadana natural gas pipeline); see also Wiwa v. Royal Dutch Petroleum, 226 F.3d 88, 92 (2000) (defendants, owners of Shell Nigeria, were charged with complicity in the 1995 hanging of Ken Saro-Wiwa and John Kpuinen, two Nigerian activists).

109. Rivera, supra note 106 , at 254.

110. See id. at 255.

111. See id. at 258.

112. Id.

113. Id.

114. See id. at 259-60.

115. Id.

116. 542 U.S. 692 (2004). 


\section{SOSA V. ALVAREZ MACHAIN}

In 1990, a federal grand jury indicted Dr. Alvarez-Machain for the torture and murder of a U.S. Drug Enforcement Agency (DEA) agent. ${ }^{117}$ The Mexican government refused to comply with the DEA's request to extradite Dr. AlvarezMachain. ${ }^{118}$ The DEA then decided to take matters into its own hands, and hired several Mexican nationals, including Francisco Sosa, in an attempt to bring Dr. Alvarez-Machain to the United States for trial. ${ }^{119}$

Francisco Sosa, along with the help of other Mexican nationals, abducted Dr. Alvarez-Machain from his home, held him overnight in a motel, and took him in a private plane to El Paso, Texas for arrest. ${ }^{120}$ In 1992, after the case went to trial, Dr. Alvarez-Machain was acquitted. ${ }^{121}$ Upon acquittal, Dr. Alvarez-Machain returned to Mexico and sued Francisco Sosa under the ATCA. ${ }^{122}$

The trial court awarded $\$ 25,000$ to Dr. Alvarez-Machain. ${ }^{123}$ The U.S. Court of Appeals for the Ninth Circuit upheld the trial court. ${ }^{124}$ As part of his abduction to the United States, the detention of Dr. Alvarez-Machain violated a clear and universal norm prohibiting arbitrary arrest and detention. This was, therefore, a violation of the law of nations. ${ }^{125}$

On September 2, 2003, Sosa filed a petition for writ of certiorari to the U.S. Supreme Court on the issue of whether the ATCA creates a cause of action. ${ }^{126}$ In October 2003, certiorari was granted, and on March 30, 2004, oral arguments were heard. ${ }^{127}$

Sosa's argument was that the ATCA provided no relief; rather, it merely vested federal courts with jurisdiction, neither creating nor authorizing the courts to recognize any particular right of action without further congressional action. ${ }^{128}$ Essentially, Sosa argued that the ATCA was not designed to be a tool to enforce international laws in U.S. courts. ${ }^{129}$

Lawyers for the U.S. Justice Department, under the George W. Bush administration, filed amicus briefs in support of Sosa's position. ${ }^{130}$ The Justice

117. U.S. Supreme Court Denies False Arrest Claim Under Alien Tort Claim Act, INTERNATIONAL Client Alert (Powell, Goldstein, Frazer \& Murphy LlP Newsletter, Atlanta, GA), Aug. 3, 2004, at 7, http://www.pogolaw.com/articles/767.pdf.

118. Id.

119. Id.

120. Id.

121. Id.

122. Id.

123. Id.

124. Id.

125. Id.

126. Id.

127. See Sosa, 542 U.S. at 692.

128. Id. at 712 .

129. See id.

130. See Sanders, supra note 47 , at 6. 
Department argued that the ATCA was being misconstrued and that the Ninth Circuit's interpretation could cause a constitutional separation of powers issue. ${ }^{131} \mathrm{~A}$ federal judge could make an independent determination of whether international laws, like the Geneva Conventions, apply in a given circumstance, regardless of the executive branch opinion. ${ }^{132}$ The Bush Justice Department argued that ATCA cases should be heard only where Congress has, by separate act, expressly given permission to file suit. ${ }^{133}$

The position of the Bush Justice Department was a reversal from the position the Department took in Filartiga during the Jimmy Carter administration. ${ }^{134}$ At that time, the Department intervened on behalf of the Filartigas to argue that human rights standards invoked by the victim reflected President Carter's view on the importance of human rights in foreign policy. ${ }^{135}$

Alvarez's position was that the ATCA is not simply a jurisdictional grant, but that it provides authority for the creation of a new cause of action for torts in violation of international law. ${ }^{136}$

On June 29, 2004, almost three months after the oral arguments, the Supreme Court handed down its decision. In a 6-3 ruling, the court reversed the $\$ 25,000$ judgment won by Dr. Alvarez-Machain. ${ }^{137}$ The Justices agreed that the ATCA is only jurisdictional. ${ }^{138}$ When it was enacted in 1789 , the ATCA gave district courts "cognizance" of certain causes of action. ${ }^{139}$ The term "cognizance" signaled a grant of jurisdiction rather than power to create substantive law. ${ }^{140}$ The Court pointed out that the ATCA was in section nine of the judiciary act, which is a statute otherwise exclusively concerned with federal jurisdiction. ${ }^{141}$

The Court then addressed the interaction between the ATCA at the time it was enacted and the surrounding law at that time. The Court ruled that federal courts could hear claims once a jurisdictional grant was "on the books" because torts in violation of the law of nations would have been recognized within the common law of that time. ${ }^{142}$ At the time of enactment, ATCA jurisdiction enabled federal courts to hear claims in a very limited category: those defined by the law of nations and recognized at common law. ${ }^{143}$ Unfortunately for Dr.

131. Id.

132. Id.

133. WHITE, supra note 72 , at xii.

134. Id.

135. Id.

136. Warren Richey, When Can Foreigners Sue In US Courts?, CHRISTIAN SCI. MONITOR, Mar. 30, 2004, www.globalpolicy.org/intljustice/atca/2004/0330when.htm.

137. Richey, supra note 9.

138. Sosa, 542 U.S. at 714.

139. Id. at 713 .

140. Id.

141. Id.

142. Id at 714 .

143. Id. 
Alvarez-Machain, his illegal one-day detention did not fall into this limited category of violations. ${ }^{144}$

Although Alvarez-Machain may have lost his battle, human rights activists may have won the war to ensure accountability for human rights violations. ${ }^{145}$ Six of the nine justices upheld the use of the ATCA statute to bring cases for serious human rights violations. ${ }^{146}$ In doing so, they may have kept the door open to allow cases by Abu-Ghraib victims, like Saleh, to proceed. ${ }^{147}$

The Court rejected arguments from the Bush administration and the business community that any claim for relief under the ATCA, a jurisdictional statute only, should require a separate statute by Congress expressly authorizing a cause of action. ${ }^{148}$ Justice Souter, writing for the majority, examined the history of cases and other legal material surrounding the ATCA and concluded that the First Congress had not passed the ATCA to be "placed on a shelf" for the future when Congress might authorize the creation of a cause of action. ${ }^{149}$

In sum, although the ATS [ATCA] is a jurisdictional statute creating no new causes of action, the reasonable inference from the historical materials is that the statute was intended to have practical effect the moment it became law. The jurisdictional grant is best read as having been enacted on the understanding that the common law would provide a cause of action for the modest number of international law violations with a potential for personal liability at the time. ${ }^{150}$

Most importantly, the Court stood by the Filartiga decision, recognizing torture as an act that was a violation of the law of nations. ${ }^{151}$ "The position we take today has been assumed by some federal courts for [twenty-four] years, ever since the Second Circuit decided Filartiga v. Pena-Irala . . .."152 However, Justice Souter directed the exercise of caution when evaluating an ATCA action and recommended giving serious weight to a case's potential impact on foreign policy. ${ }^{153}$

Justice Scalia concurred in the judgment, but he wrote a separate opinion expressing his view that a cause of action should not be heard under the ATCA

144. Id. at 2762 .

145. Marcia Coyle, Justices Open Door with Alien Tort Case; What Kind of Claims Remain is Contested, 26 NAT'L L. J. 1 (July 5, 2004).

146. Sosa, 542 U.S. at 724.

147. See id.

148. Coyle, supra note 145.

149. Sosa, 542 U.S. at 719.

150. Id. at 724 .

151. Id. at 731 .

152. Id.

153. Press Release, EarthRights International, ATCA Lives! (June 29, 2004), at http://www.earthrights.org/news/atcalives.shtml. 
without specific congressional action. ${ }^{154}$ Scalia did not dispute that ATCA jurisdiction was originally available to enforce a small number of international norms without further statutory authority. ${ }^{155} \mathrm{He}$ argued, however, that since Erie Railroad Co. v. Tompkins, ${ }^{156}$ there has been a limitation on federal judicial power. According to Erie, federal courts have no authority to derive "general" common law. ${ }^{157}$ Erie reversed the holding of Swift $v$. Tyson, ${ }^{158}$ which allowed federal courts to express their own opinions on general commercial law. ${ }^{159}$

Erie recognized the problems that existed when federal courts choose general common law ${ }^{160}$ and ruled that " $[t]$ here is no federal general common law." "The lesson of Erie, according to Scalia, is that grants of jurisdiction by themselves are not grants of lawmaking authority. Since the ATCA is only jurisdictional in nature, there can be no claims recognized under the Act. ${ }^{162}$ Scalia believes that unless Congress authorizes each ATCA cause of action, it is an unlawful exception to the Erie rule that general common law does not exist. $^{163}$

The majority disagreed with Scalia's interpretation of Erie, responding: "Erie did not in terms bar any judicial recognition of new substantive rules, no matter what the circumstances, and post-Erie understanding has identified limited enclaves in which federal courts may derive some substantive law in a common law way." 164

The First Congress understood that the district courts would recognize private causes of action for certain torts in violation of the law of nations. ${ }^{165}$ According to Sosa, any claim based on the present-day law of nations should "rest on a norm of international character accepted by the civilized world and defined with a specificity comparable to the features of the $18^{\text {th }}$ century ...",166 The Sosa Court reasoned that the First Congress knew that federal courts could properly identify some international norms as enforceable in the exercise of ATCA jurisdiction. $^{167}$ It would be unreasonable to assume that the First Congress, in enacting the ATCA, expected federal courts to lose their ability to recognize enforceable international norms and require special congressional authorization. $^{168}$

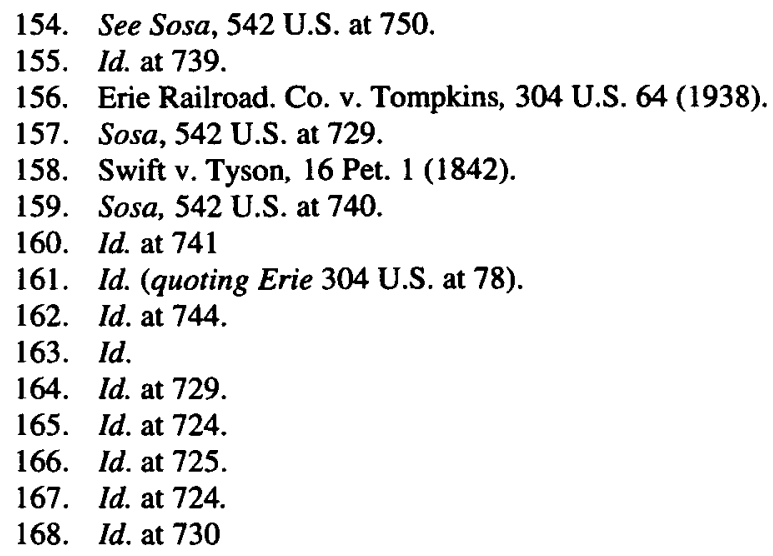


The Sosa decision also reinforced the standard of identifying the law of nations set forth in Filartiga. ${ }^{169}$ Alvarez's detention claim needed to be gauged against the sources of international law that had been recognized in the past. ${ }^{170}$ The Law of nations come primarily from treaties, the legislature, or judicial decisions. If these do not exist, one must look to the customs of civilized nations. ${ }^{171}$

[W]here there is no treaty, and no controlling executive or legislative act or judicial decision, resort must be had to the customs and usages of civilized nations; and, as evidence to these, to the works of jurists and commentators, who by years of labor, research and experience, have made themselves peculiarly well acquainted with the subjects of which they treat. $^{172}$

The significance of the Sosa decision is that ATCA claims limited to violations of certain widely accepted international norms, like torture, are actionable in U.S. courts. ${ }^{173}$

\section{ESTABLISHING LIABILITY UNDER THE ATCA}

The landmark rulings in Filartiga, Kadic, and Sosa suggest that victims of Abu-Ghraib have a two-prong test to determine if they have a valid ATCA claim. First, they need to establish that the violations were enough to be considered modern day violations of the law of nations. Second, according to the standard established in Kadic, they need to establish that their abuse was sufficient to warrant action against private actors. If victims of Abu-Ghraib prove that they were tortured by private contractors in the course of a war, they will have satisfied both prongs of this test. The court in Filartiga acknowledged torture as a violation of the laws of nations. ${ }^{174}$ In Kadic, the court identified torture conducted during hostilities as serious enough to allow a claim against a non-state actor. ${ }^{175}$ Perhaps the biggest obstacle for victims of Abu-Ghraib will be to establish that their treatment went beyond humiliating and rose to the level universally accepted as torture. ${ }^{176}$

Defense attorneys for the soldiers who have been charged under military law for their role in the abuse at Abu-Ghraib have raised doubts as to the

169. See id. at 732.

170. Id

171. Id. at 734.

172. Id.

173. See id. at 732.

174. Filartiga, 630 F.2d at 880 .

175. Kadic, 70 F.3d at 242.

176. See infra section $\mathrm{V}$. 
severity of the abuse that took place. ${ }^{177}$ In opening statements heard on January 10,2004 , in the criminal proceedings against Specialist Charles Graner, Graner's defense attorney argued that the actions of his client fell short of torture. ${ }^{178} \mathrm{He}$ compared stacking nude prisoners in a pyramid to stacking cheerleaders in pyramids at sporting events throughout the United States. ${ }^{179}$ According to Graner's defense, a prisoner with dog leashes around his neck is no different than a parent attaching a tether to their child at a mall. ${ }^{180}$

The defense raised by Graner was ultimately unsuccessful. Nevertheless, it should caution potential plaintiffs in ATCA actions against military contractors of the obstacles they will surely face. Plaintiffs will have to distinguish between acts that were actually torture and those, although humiliating, that fall short of torture.

The exact definition of torture is a question that came up during the 2004 confirmation hearings of U.S. Attorney General Alberto Gonzales. Mr. Gonzales was questioned about his judgment in endorsing the Justice Department's controversial definition of torture while he served as White House Counsel. ${ }^{181}$ The Justice Department has since shied away from their original definition on torture. On December 30, 2004, the Justice Department published a revised definition of acts that constitute torture under domestic and international law. ${ }^{182}$ The previous memo, dated August 2002, stated that only actions that cause organ failure, impairment of bodily functions, or death constitute torture punishable by law. ${ }^{183}$ According to the new memo, torture may consist of acts that fall short of provoking excruciating and agonizing pain and may include physical suffering or lasting mental anguish. ${ }^{184}$ The new memorandum declares that "torture is abhorrent both to American law and values and to international norms. ${ }^{185}$ This statement encapsulates the position that U.S. courts have taken on torture. The document directly contradicts the previous version and says that torture need not be limited to pain "equivalent in intensity to the pain accompanying serious physical injury, such as organ failure, impairment of bodily function, or even death. "186 Instead, the memo concludes that anti-torture laws passed by Congress equate torture with physical suffering "even if it does not involve severe physical pain," but it still must be

177. BBC News, Abu Ghraib Troops 'Did Not Abuse' (Jan. 11, 2005), at http://news.bbc.co.uk/2/hi/middle_east/4155375.stm.

178. Id.

179. Id.

180. Id.

181. See R. Jeffrey Smith \& Dan Eggen, Justice Expands 'Torture' Definition, WASHINGTON POST, Dec. 31, 2004, at Al, http://www.washingtonpost.com/wpdyn/articles/A37687-2004Dec30.html.

182. Id.

183. Id.

184. Id.

185. Id.

186. CNN Online, U.S. revises its definition of torture (Dec 31, 2004), at http://www.cnn.com/2004/LAW/12/31/justice.torture.memo.ap. 
more than "mild and transitory." 187 In addition, the memo states that U.S. personnel involved in interrogations cannot contend that their actions were motivated by national security needs or other reasons. ${ }^{188}$ This revised definition brings the U.S. definition of torture in line with the definition under the United Nations Universal Declaration of Human Rights, the same declaration the Filartiga court referred to in defining torture. ${ }^{189}$ The U.N. declaration reads:

Article 1

1. For the purpose of this Declaration, torture means any act by which severe pain or suffering, whether physical or mental, is intentionally inflicted by or at the instigation of a public official on a person for such purposes as obtaining from him or a third person information or confession, punishing him for an act he has committed or is suspected of having committed, or intimidating him or other persons. It does not include pain or suffering arising only from, inherent or incidental to lawful sanctions to the extent consistent with the Standard Minimum Rules for the Treatment of Prisoners.

2. Torture constitutes an aggravated and deliberate form of cruel, inhuman of degrading treatment or punishment.

Article 3

No state may permit or tolerate torture or other cruel, inhuman or degrading treatment or punishment. Exceptional circumstances such as a state of war or threat of war, internal political instability or any other public emergency may not be invoked as a justification of torture or other cruel, inhuman or degrading treatment or punishment. ${ }^{190}$

Plaintiffs in an action against military contractors may be able to establish that they were tortured if they are able to provide evidence showing that they were inflicted with severe pain in an attempt to get intelligence information.

The evidence of the alleged abuse at Abu-Ghraib that has surfaced thus

187. Id.

188. Id.

189. Filartiga, 630 F.2d at 882.

190. Id. at 883 (quoting General Assembly Resolution 3452, 30 U.N. GAOR Supp. (No. 34) 91, U.N. Doc. A/1034 (1975). 
far suggests that prisoners in Iraq were indeed tortured. Sheriff Akeel, an attorney involved in a lawsuit against $\mathrm{CACI}$ and Titan on behalf of Abu-Ghraib victims, has found disturbing evidence about the extent of abuse. ${ }^{191}$ Akeel went on a fact-finding mission in Baghdad, uncovering dozens of cases of psychological abuse, sexual humiliation, religious desecration, and rape in prisons run by the United States throughout Iraq, including Abu-Ghraib. ${ }^{192}$ His team documented abuse dating from July 2003 to as recently as August 2004. ${ }^{193}$ The most recent incident is that of a fifteen-year-old Iraqi boy who claims he was raped by his captors. ${ }^{194}$ In one case, a naked woman wearing a strap-on sexual device raped an elderly Iraqi man. ${ }^{195}$ In another instance, a woman claimed that during her first night of incarceration, she witnessed an imprisoned man and woman raped. ${ }^{196}$ In another account, a doctor was taken to AbuGhraib prison where he watched a naked prisoner forced onto the running engine of a Humvee, leaving the man with severe burns. ${ }^{197}$ The cases of abuse go on, and they are extremely disturbing.

Saleh, the Swedish citizen who was thrown into Abu-Ghraib, is now a client of Akeel. ${ }^{198}$ Saleh claims he was dragged for seventy feet with a belt tied around his neck. ${ }^{199} \mathrm{He}$ was also left naked and hooded for extended periods of time. ${ }^{200} \mathrm{He}$ was urinated on and sodomized while his hands were tied over his head. ${ }^{201}$ At one point, Saleh was shot in the chest with plastic bullets as he tried to pray. ${ }^{202}$ Saleh also claims that that he was roped by the genitals to twelve other naked prisoners; his penis was stretched with a rope and beaten with a stick. $^{203}$ He also claims that one night he heard the screams of a female prisoner whom he believes was being raped. ${ }^{204}$ The statements of these victims will play an important role in establishing that the abuse at Abu-Ghraib rose to the level of torture.

Allegations of the abuse at Abu-Ghraib have also been substantiated through the discovery of extremely graphic photographic evidence. ${ }^{205}$ Some of these pictures were seen around the world after first being aired on a CBS 60

191. Lisa Ashkenaz Croke, American Lawyer Finds New Evidence of Recent Torture in $\begin{array}{lllll}\text { Iraq, THE NEW STANDARD, 27, } & \text { Sept. }\end{array}$ http://newstandardnews.net/content?action=show_item\&itemid=911 .

192. Id.

193. Id.

194. Id.

195. Id.

196. Id.

197. Id.

198. Seth Hettena, Iraqi in Abu Ghraib Saw Captors Rape, Kill Detainees, Associated Press, July 4, 2004, at http://www.indymedia.org.uk/en/2004/07/294376.html.

199. Id.

200. Id.

201. Id.

202. Id.

203. Id.

204. Id.

205. Taguba Report, supra note 43, at 14. 
Minutes Two broadcast on April 28, 2004. ${ }^{206}$ There was one photo which showed the battered face of a deceased prisoner, No. 153399. ${ }^{207}$ Another photo was of the bloodied body of a dead prisoner wrapped in cellophane and packed in ice. ${ }^{208}$ According to U.S. Defense Secretary Donald Rumsfeld's statement before a Senate Armed Services panel, there are many more photos and videotapes related to the Iraq abuse scandal. ${ }^{209}$ "There are a lot more photographs and videos that exist. If these are released to the public, obviously it's going to make matters worse." 210 The photographic evidence will play an important role in verifying the horrific stories of the abused at Abu-Ghraib.

Prison victims will also need to prove that the torture they suffered was at the hands of the civilian contractors. Distinguishing between which acts of abuse were committed by U.S. military personnel and which ones were committed by civilian contractors will be difficult. Interrogators often wore U.S. military uniforms, and the abusers usually approached victims from behind, which makes identification difficult. ${ }^{211}$

Findings from the criminal proceedings against soldiers who have been charged for their roles in the abuse can aid in implicating private contractors. Also, independent military investigations, such as those conducted by General Taguba, describe the involvement of private contractors and will be essential in proving their culpability.

For instance, investigators involved in the prosecution of Sergeant Chip Fredrick uncovered letters and emails written by Fredrick implicating private contractors. $^{212}$ In his letters, Fredrick noted that the Military Intelligence teams, which included linguists and interrogation specialists from private defense contractors, were the dominant force inside Abu-Ghraib. ${ }^{213}$ He wrote about Military Intelligence encouraging soldiers to continue with their abuse of prisoners, as it was providing positive results and information. ${ }^{214}$

In one letter, written in November 2003, Fredrick describes the great lengths taken to cover up evidence of abuse. ${ }^{215}$ An Iraqi prisoner under the control of the CIA and its paramilitary employees, including private contractors, died in the course of interrogations. ${ }^{216}$ Fredrick described the cover up: "[T]hey put his body in a bag and packed him in ice for approximately twenty four hours in the shower... . The next day the medics came and put his

206. Hersh, supra note 22.

207. Id.

208. Id.

209. People's Daily Online, Rumsfeld Says More Photos, Videos in Abuse Scandal Exist, at http://english.people.com.cn/200405/08/eng20040508_142575.html (May 8, 2004).

210. Id.

211. Croke, supra note 191.

212. See Hersh, supra note 22.

213. Id.

214. Id.

215. Id.

216. Id. 
body on a stretcher, placed a fake IV in his arm and took him away."217 The inmate was never entered into the prison's inmate control system. ${ }^{218}$

Fredrick claims that contractors were directing U.S. soldiers. ${ }^{219} \mathrm{He}$ specifically identified two CACI employees as having instructed him. ${ }^{220}$ Steven A. Stefanowicz, a CACI interrogator, ordered him to use dogs to threaten prisoners. ${ }^{221}$ In one instance, Stefanowicz said: "Treat "em like [expletive]. Put the dog on this one if you can." 222 Fredrick also testified that another CACI employee, Mr. Johnson, instructed him to apply pressure under the jaw and behind the ears, or on the cheeks of Iraqi prisoners during interrogations. ${ }^{223}$ These accounts illustrate that private contractors were directly involved in the abuse and had a great deal of control over the prison. ${ }^{224}$

Independent military investigation findings such as the Taguba Report and Fay Report also verify the abuse that went on inside Abu-Ghraib. According to the Taguba Report, between October and December 2003, there were numerous instances of abuse of prisoners held at Abu-Ghraib. ${ }^{225}$ The Taguba Report notes that U.S. civilian contract personnel were not properly supervised within the detention facility at Abu-Ghraib. ${ }^{226}$ During General Taguba's onsite inspection, he observed contractors wandering about with too much unsupervised free access in the detainee area. ${ }^{227}$

The Taguba report made numerous recommendations relating to the private contractors. For instance, it recommended that $\mathrm{Mr}$. Steven Stephanowicz, a CACI interrogator in the $205^{\text {th }}$ Military Intelligence Brigade, be given an official reprimand to be placed in his employment file, termination of employment, and the revocation of his security clearance. ${ }^{228}$ The report found that Stephanowicz made false statements to the investigation team regarding the locations of his interrogations, his involvement in the interrogations, and his knowledge of abuse. ${ }^{229}$ Stephanowicz allowed and instructed Military Police, who were not trained in interrogation techniques, to facilitate interrogations by "setting conditions" that were neither authorized nor

217. Id.

218. Id.

219. Jackie Spinner, MP Gets 8 years for Iraq Abuse, ThE WASHINGTON POST, Oct. 22, 2004, at A20.

220. Id.

221. Id.

222. Id.

223. Id.

224. Id.

225. Taguba Report, supra note 43, at 14.

226. See generally Taguba Report, supra note 43.

227. Id. at 24.

228. Id. at 41-42.

229. Id. at 42. 
in accordance with applicable regulations. ${ }^{230}$ Taguba notes that Stephanowicz clearly knew his instructions equated to physical abuse. ${ }^{231}$

The report also implicated Mr. John Israel, a contract U.S. civilian interpreter from the $205^{\text {th }}$ Military Intelligence Brigade, also an employee of $\mathrm{CACI}^{232}$ It was recommended that he be given an official reprimand to be placed in his employment file and have his security clearance reviewed. ${ }^{233}$ General Taguba concluded that Stephanowicz and Israel were either directly or indirectly to blame for some of the abuses at Abu-Ghraib and recommended immediate disciplinary action. ${ }^{234}$

Another military investigation conducted by Major General George Fay and published in the Fay Report also details the extent of private contractor involvement at Abu-Ghraib. ${ }^{235}$ His investigation concluded that fifty-four military intelligence officers, military police, medical soldiers, and civilian contractors had some degree of responsibility in the alleged Abu Ghraib abuse. $^{236}$ The report states that soldiers were actually supervised by private contractors. $^{237}$ The Fay Report graphically details forty-four incidents of alleged abuse at Abu-Ghraib involving military intelligence personnel and contractors. $^{238}$ Of the forty-four documented incidents from July 2003 to February 2004, employees from CACI and Titan are accused of involvement in fourteen of them. ${ }^{239}$ The report also describes findings of stripping prisoners, forcing detainees to masturbate, perform sex acts, and the use of un-muzzled dogs to threaten detainees. ${ }^{240}$ The Fay Report states that thirty-five percent of the interrogators provided on contract by CACI did not have formal military training as interrogators. ${ }^{241}$ One disturbing account in the Fay Report describes a CACI contractor who was dragging a handcuffed prisoner at Abu-Ghraib while drinking alcohol. ${ }^{242}$ The contractor is cited as being belligerent to military command and, at one point, was so angered because someone had questioned his conduct that he responded by saying, "I have been doing my job for 20 years and do not need a 20 -year old to tell me how to do my job."243

230. Id.

231. Id.

232. Id.

233. Id.

234. Id.

235. Marty Logan, Victims' Lawyers Laud Abu Ghraib Reports, Inter Press Service News Agency, at http://www.ipsnews.net/interna.asp?idnews $=25287$ (Aug. 31, 2004).

236. Id.

237. Id.

238. Mike Lee, Private Contractors Face Legal Action for Crimes in Abu Ghraib, The Mail Archive, at http://www.mail-archive.com/osint@yahoogroups.com/msg00383.html (Sept 15. 2004).

239. Id.

240. Id.

241. Id.

242. Id.

243. Id. 
The specific tactics used to abuse prisoners suggest that the abuse was part of a well-planned scheme to break down prisoners. This was more than a few renegade soldiers acting on their own. ${ }^{244}$ Some of the reported cases of abuse suggest a unique understanding of Arab culture and Islamic law. ${ }^{245}$ The particular methods of abuse appear to have been planned with an eye towards the particular sensitivities of people from the Arab and Muslim world. ${ }^{246}$ For instance, forcing Muslim prisoners to pray to a pig or pouring alcohol on a Muslim prisoner suggests that abusers knew that both pork and alcohol are forbidden under Islamic law. ${ }^{247}$ There is also an account of a prisoner being raped while he was fasting, which violates an Islamic law requiring a Muslim to refrain from any sexual activity while fasting. ${ }^{248}$ Having men photographed nude as they partake in homosexual acts is also particularly dehumanizing in the Arab world. ${ }^{249}$ Homosexual acts are against Islamic law, and it is considered humiliating for men to be naked in front of other men. ${ }^{250}$

Gary Myers, a defense attorney for Sergeant Chip Fredrick, believes that there was a higher level of involvement in determining which abusive practices to use. ${ }^{251}$ In a statement in defense of his client he said, "Do you really think a group of kids from rural Virginia decided to do this on their own? Decided that the best way to embarrass Arabs and make them talk was to have them walk around nude?"252 Plaintiffs can point to this almost methodical approach in deciding which interrogation techniques to use in order to establish a higher level of corporate involvement.

The combination of victim accounts, graphic photos, findings from the criminal prosecution of soldiers, and the military investigation reports establish a pattern of abuse at Abu-Ghraib. This evidence will be instrumental in demonstrating the extent of private contractor involvement in the abuse. It will also be necessary to show that the abuse at Abu-Ghraib reached the threshold necessary to bring an ATCA action.

\section{PENDING LITIGATION}

In June 2004, a human rights group, the Centre for Constitutional Rights (CCR) -the same group that helped Dolly Filartiga with her lawsuit - and other lawyers filed a class action suit in San Diego, California against Titan and

244. See generally Hersh, supra note 22 .

245. See id.

246. See id.

247. Croke, supra note 185 .

248. Id.

249. See Hersh, supra note 22.

250. Id.

251. Id.

252. Id. (quoting Gary Myers, a defense attorney for Chip Fredrick). 
CACI for abuses committed by their employees at prisons in Iraq. ${ }^{253}$ Most of the accounts of abuse are tied to Abu-Ghraib and range from beatings and sleep deprivation, to interference with prayers and sexual humiliation. ${ }^{254}$ One plaintiff claims that a female conspirator raped him. ${ }^{255}$ Another plaintiff claims that his father was beaten to death. ${ }^{256}$ The complaint alleges that the companies knew that the amount of interrogation contracts they would win from the government was related to the amount of information obtained during the interrogations. $^{257}$

Plaintiffs contend that CACI and Titan did not want efforts to acquire information hampered by the mandates of the U.S. domestic and international law. ${ }^{258}$ Plaintiffs are trying to establish that the contractors intended to create an environment where prisoners were being tortured, abused, and mistreated so that they would provide more intelligence, which would ultimately lead to more government contracts. $^{259}$

The motions to dismiss, which have been filed by CACI and Titan, provide an idea of the obstacles that plaintiffs will face in prosecuting these companies. For instance, in its motion to dismiss, Titan shifts the blame to the U.S. government. ${ }^{260}$ The motion states that the government was closely involved in recruiting the Titan translators. ${ }^{261}$ Titan claims that the government dictated detailed translator qualifications and conducted investigations and security screenings of translators before hiring. ${ }^{262}$ Once hired, the government provided required training and briefings to the civilian translators. ${ }^{263}$ Titan says that the government had the authority to remove a contract employee and should hold ultimate responsibility. ${ }^{264}$

There is also some case law which provides immunity to contractors and military personnel in times of combat. Although holding military contractors liable under the ATCA will be a case of first impression, defendants will insist that courts look to other statutes, such as the Federal Tort Claims Act (FTCA) for guidance on how to apply the ATCA. ${ }^{265}$

253. Shannon O'Leary, Iraq Prison Abuse Suit Targets U.S. Companies, CORPORATE LEGAL Times, Sept. 2004, at 82.

254. Id.

255. Id.

256. Id.

257. Class Action Complaint filed against Titan and CACI by victims of Abu Ghraib, 12 (2004) (on file with author).

258. Id. at 16 .

259. Id.

260. Titan's Motion to Dismiss, supra note 14, at 8.

261. Id. at 8-9.

262. Id. at 9 .

263. Id.

264. See id.

265. Id. at 12-13. 
According to the FTCA, the government can be sued only where a private person could be liable for the same offense. ${ }^{266}$ However, the FTCA bars claims where they arise out of combatant activities. ${ }^{267}$ This is meant to prevent dragging the government into court for the damage and suffering that is inevitable during war. ${ }^{268}$ Defendants are trying to persuade the court that the same rationale for preventing a lawsuit as a result of combatant activities under the FTCA should apply to the ATCA because the government has the same interests during a time of war. Titan raised this argument in its motion to dismiss and cited to its success in the Ninth Circuit in Koohi v. United States. ${ }^{269}$

The Koohi case stems from an incident that occurred on July 3, 1988. ${ }^{270}$ The USS Vincennes, a naval cruiser which was equipped with a computerized Aegis air defense system, mistook a civilian aircraft, Iran Air Flight 655, for an Iranian F-14 and shot it down over the Persian Gulf, killing all 290 persons aboard. ${ }^{271}$ The heirs of some of the deceased passengers and crew filed suit, seeking compensation from the United States and several private companies who were involved in the construction of the Aegis Air Defense System. ${ }^{272}$ The plaintiffs claimed that the weapons manufacturers were responsible for design defects that caused the misidentification of the civilian aircraft. ${ }^{273}$

The Koohi court held that contractors who provide support to the military in a time of war owe no duty of care to enemy civilians injured as a result of military operations. ${ }^{274}$ The court ruled that because the incident took place during "combatant activities," the U.S. government had immunity. ${ }^{275}$

The purpose of providing the combatant exception to U.S. military forces is to ensure that the government will not be liable for negligent conduct by armed forces in times of combat. ${ }^{276}$ The court perceived three reasons for the combatant activities exception. ${ }^{277}$ First, tort law is based on the theory that the prospect of liability is a deterrent and causes people to exercise caution. ${ }^{278}$ Congress would not want our military personnel to exercise great caution during battle when they may need to overcome enemy forces. ${ }^{279}$ Second, tort law is based on a desire to provide a remedy for the innocent victim of wrongful conduct. ${ }^{280}$ War produces many innocent victims on all sides, and it

266. Federal Tort Claims Act, \& 28 U.S.C. § 1346(b).

267. Titan's Motion to Dismiss, supra note 14, at 13.

268. See Koohi v. United States, 976 F.2d 1328 ( $9^{\text {th }}$ Cir. 1992).

269. Id.

270. Id. at 1330.

271. Koohi, 976 F.2d at 1330.

272. Id.

273. Id.

274. Id. at 1336.

275. Id. at 1335.

276. Id. at 1334 .

277. $1 d$.

278. Id.

279. Id. at 1334-35.

280. Id. at 1335 . 
would make little sense to single out for special compensation enemy citizens on the idea that they have suffered negligence from the military. ${ }^{281}$ Third, tort law is often used to obtain punitive damages. ${ }^{282}$ It is unlikely that Americans would support punishing our servicemen for injuring members of the enemy population in an effort to preserve their own lives. ${ }^{283}$ These are the main reasons that tort law is inappropriate during military operations. ${ }^{284}$

The court held that the action against Aegis was preempted by the "combatant activities" exception. 285 "While the purpose of the Aegis system may have been, in part, to protect the lives of United States servicemen, its purpose surely was not to protect the lives of enemy forces or persons associated with those forces." ${ }^{286}$ According to Koohi, the FTCA provides a military contractor protection under all circumstances for actions in support of combatant activities, whether the challenged actions were taken "carefully or negligently, properly or improperly."287 The court dismissed the claims against the government contractor on the basis that "[t]he imposition of such liability on the [contractors] would create a duty of care where the combatant activities exception is intended to ensure that none exists."288

CACI, in its motion to dismiss, raises similar arguments, accusing the plaintiffs of seeking recovery through the "back door" for injuries supposedly caused by the U.S. government's invasion of Iraq. ${ }^{289}$ CACI asserts that the suit must be dismissed because the claims present a nonjusticiable political question. ${ }^{290}$ It argues that the plaintiffs are seeking compensation for injuries allegedly received during the prosecution of a war, and this type of compensation is for the political branches of government to resolve. ${ }^{291} \mathrm{CACI}$ points to precedent from both the Supreme Court and the Ninth Circuit which prevents evasion of the federal government's immunity through suits against government contractors. ${ }^{292}$

281. Id.

282. Id.

283. Id.

284. Id.

285. Id. at 1337

286. Id.

287. Titan's Motion to Dismiss, supra note 14, at 14 (quoting Koohi, 976 F.2d at 1335) (dismissing tort claims against military contractors for war related deaths of civilians when the military fired missiles upon an Iranian civilian airliner).

288. Id. (quoting Koohi, 976 F2d at 1337).

289. Memorandum of Points and Authorities in Support of the Motion of Defendants CACI Inc.'s Motion to Dismiss, 14 (September 14, 2004) (on file with author) [hereinafter CACl's Motion to Dismiss].

290. Contractors move to Dismiss Iraqi Prisoners' Suit, ANDREWS Class ACTION LITIGATION REPORTER, Oct. 21, 2004.

291. Id.

292. CACl's Motion to Dismiss, supra note 292, at 14 (quoting Stencel Aero Eng'g Corp. v. United States, 431 U.S. 666, 673 (1977)); see McKay v. Rockwell Int'l Corp, 704 F.2d 444, $449\left(9^{\text {th }}\right.$ Cir. 1983). "To permit [petitioner] to proceed here would be to judicially admit at the 
However, it can be argued that Abu-Ghraib went beyond what is considered "authorized military action." When the limits on the FTCA were set out, the court was probably thinking about conduct that was within the boundaries of the laws of war. The court did not want contractors to be sued for injuries that take place in the ordinary course of a war. ${ }^{293}$ In Koohi, the action was a negligence action against weapons manufactures who may have built a faulty weapons system that failed to detect a civilian airliner. ${ }^{294}$ The court was correct to rule that there was no duty of care owed by the manufacturers of weapons systems to enemies. The torture at Abu-Ghraib is distinguishable; it crosses the line of what is acceptable, even in times of war. Torture is a violation of the laws of war. ${ }^{295}$ The limitations of the FTCA, with respect to contractors in war that were discussed in Koohi, should not provide immunity for those involved in the torture at Abu-Ghraib.

Another defense for the civilian contractors will come from the dicta in Justice Souter's opinion in Sosa. In Sosa, the Court spoke of exercising judicial caution when considering the kinds of individual claims that might implement the jurisdiction conferred by the ATCA. ${ }^{296}$ The main concern was the possibility of lawsuits infringing on the U.S. government's ability to conduct foreign affairs. ${ }^{297}$ Private contractors argue that the handling of prisoners in a time of war involves issues that deal with the particularly sensitive area of foreign relations. ${ }^{298}$ Claims arising out of the manner in which the United States wages an external war may be inappropriate for the creation of a private cause of action under the ATCA. ${ }^{299}$ The defendants assert that claims arising out of war have always been resolved on a government-togovernment basis and that allowing a private cause of action infringes on the executive branch's role of establishing American foreign policy. ${ }^{300}$

It is quite probable that the justices had the current "war on terror" on their minds when they issued the Sosa opinion. If Abu-Ghraib prisoners are awarded damages, it may open the floodgates for other prisoners in U.S. custody, like those in Guantanamo Bay, being held in the United States's prosecution of the "war on terror." The United States may be forced to spread its military thin in this new kind of war, resulting in an increased reliance on private companies in the future. Any court will have to consider what a victory for the prisoners against civilian contractors assisting U.S. military personnel will have on the United States's ability to carry out its foreign policy objectives.

This author contends that any argument suggesting that holding private

back door that which has been legislatively turned away at the front door. We do not believe that the [Federal Tort Claims Act] permits such a result." Id.

293. See Koohi, 976 F.2d at 1336.

294. Id. at 1330.

295. Kadic, 70 F.3d at 242.

296. Sosa, 542 U.S. at 725 .

297. Id. at 727.

298. CACl's Motion to Dismiss, supra note 292, at 26.

299. Id.

300. Id. 
corporations accountable for acts of torture will somehow hinder the U.S.-led War on Terror is weak. American military personnel and military contractors should not be engaged in torture under any circumstances; this is now the official policy of the Justice Department. ${ }^{301}$ Providing immunity in cases where Americans have committed torture may prove to be more harmful to U.S. foreign policy because it harms the United States's reputation abroad and questions the authenticity of any intentions to spread liberty.

Furthermore, if the U.S. protects torturers in the name of foreign policy, it may endanger the safety of Americans who may one day find themselves in enemy prisons. ${ }^{302}$ Perhaps Brigadier General Mark Kimmitt, deputy director of operations for the U.S. military in Iraq, said it best: "If we can't hold ourselves up as an example of how to treat people with dignity and respect, we can't ask that other nations to do that to our soldiers." 303

In an article written to the New York Times dated August 7, 2003, Arlen Specter, who is now the Chairman of the U.S. Senate Judiciary Committee, expressed his opposition to the Justice Department's view that ATCA litigation may affect the "War on Terror."

There is no room for moral relativism. American credibility in the war on terrorism depends on a strong stand against all terrorist acts, whether committed by foe or friend. Our credibility in the war on terrorism is only advanced when our government enforces laws that protect innocent victims. We then send the right message to the world: The United States is serious about human rights. ${ }^{304}$

\section{CONCLUSION}

Litigation under the ATCA has an important impact on an alien plaintiff's ability to receive civil remedies. ${ }^{305}$ The importance of the ATCA to victims and their families, however, goes beyond just monetary damages. ${ }^{306}$ For years, the ATCA has been a tool to allow plaintiffs to tell their stories to a court and give them an opportunity to confront their abusers and create an

301. See CNN Online, U.S. revises its definition of torture, at http://www.cnn.com/2004/LAW/12/31/justice.torture.memo.ap/ (Dec 31, 2004).

302. See generally Borger, supra note 51.

303. Id.

304. Arlen Specter, The Court of Last Resort, N.Y. TIMES, August 7, 2003, available at www.globalpolicy.org/intljustice/atca/2003/0807specter.htm.

305. See generally Filartiga, 630 F.2d at 876 (sister of torture victim who brought ATCA action was awarded over ten million dollars).

306. Michael Ratner, Civil Remedies for Gross Human Rights Violations, at http://www.humanrightsnow.org/Ratner2\%20david\%20ratner\%20corrections\%20final\%20num bered.htm (last visited Feb 20, 2005). 
official record of their persecutions. ${ }^{307}$ Filing civil suits empowers victims. ${ }^{308}$ It gives them a means for fighting back. ${ }^{309}$ It can also help them heal. ${ }^{310}$ Recent decisions involving the ATCA have helped to establish the scope of the Act and have made it a likely avenue for victims of the alleged Abu-Ghraib prison abuse to seek relief in U.S. courts.

Attempts by the Bush Administration and some multinational corporations to severely limit the scope of the ATCA failed in the recent decision of Sosa v. Alvarez-Machain. The Sosa Court ruled that although the ATCA is only jurisdictional, it may provide a cause of action in a limited number of cases involving violations of the law of nations. ${ }^{311}$ The Sosa decision will be instrumental for victims of Abu-Ghraib prison abuse to demonstrate that the ATCA is a legitimate avenue for them to seek compensation for the wrongs they suffered at the hands of civilian contractors.

The evidence of the abuses suffered by the Iraqis who were held at the Abu-Ghraib prison illustrates that the treatment of the prisoners may very well have been severe enough to classify as torture. It also seems apparent that at least some of this torture was directed by civilian contractors. If not for the ATCA, these contractors would go unpunished because they are immune from both military law and prosecution in Iraqi courts. ${ }^{312}$ The ATCA may enable U.S. courts to serve as a court of last resort and help victims like Saleh bring their abusers to justice.

On May 6, 2004, President George W. Bush expressing his sorrow to the victims of Iraqi prison abuse stated that "wrongdoers will be brought to justice" and "the actions of those folks in Iraq do not represent the values of the United States of America." 313 Ironically, it may be the ATCA, to which the Bush administration was adamantly opposed, that actually helps the President keep his promise to the Iraqis.

307. Id.

308. Id.

309. Id.

310. Id.

311. See Sosa, 542 U.S. at 729.

312. Mariner, supra note 5.

313. Sean Murphy, U.S. Abuse of Iraqi Detainees at Abu Ghraib Prison, 98 AM. J. INT'L L. 591,596 (2004). 
